\title{
EFFECTS OF MANAGEMENT PRACTICES ON GRASSLAND BIRDS: LE CONTE'S SPARROW
}



Grasslands Ecosystem Initiative

Northern Prairie Wildlife Research Center U.S. Geological Survey Jamestown, North Dakota 58401 
This report is one in a series of literature syntheses on North American grassland birds. The need for these reports was identified by the Prairie Pothole Joint Venture (PPJV), a part of the North American Waterfowl Management Plan. The PPJV recently adopted a new goal, to stabilize or increase populations of declining grassland- and wetland-associated wildlife species in the Prairie Pothole Region. To further that objective, it is essential to understand the habitat needs of birds other than waterfowl, and how management practices affect their habitats. The focus of these reports is on management of breeding habitat, particularly in the northern Great Plains.

Suggested citation:

Dechant, J. A., M. L. Sondreal, D. H. Johnson, L. D. Igl, C. M. Goldade, A. L. Zimmerman, and B. R. Euliss. 1998 (revised 2002). Effects of management practices on grassland birds: Le Conte's Sparrow. Northern Prairie Wildlife Research Center, Jamestown, ND. 15 pages.

Species for which syntheses are available or are in preparation:

American Bittern

Mountain Plover

Marbled Godwit

Long-billed Curlew

Willet

Wilson's Phalarope

Upland Sandpiper

Greater Prairie-Chicken

Lesser Prairie-Chicken

Northern Harrier

Swainson's Hawk

Ferruginous Hawk

Short-eared Owl

Burrowing Owl

Horned Lark

Sedge Wren

Loggerhead Shrike

Sprague's Pipit
Grasshopper Sparrow

Baird's Sparrow

Henslow's Sparrow

Le Conte's Sparrow

Nelson's Sharp-tailed Sparrow

Vesper Sparrow

Savannah Sparrow

Lark Sparrow

Field Sparrow

Clay-colored Sparrow

Chestnut-collared Longspur

McCown's Longspur

Dickcissel

Lark Bunting

Bobolink

Eastern Meadowlark

Western Meadowlark

Brown-headed Cowbird 


\section{EFFECTS OF MANAGEMENT PRACTICES ON GRASSLAND BIRDS:

\author{
LE CONTE'S SPARROW
}

Jill A. Dechant, Marriah L. Sondreal, Douglas H. Johnson, Lawrence D. Igl, Christopher M. Goldade, Amy L. Zimmerman, and Betty R. Euliss

Series Coordinator: Douglas H. Johnson

Series Assistant Coordinator: Lawrence D. Igl

Reviewers: Brenda C. Dale and Bertram G. Murray, Jr.

Range Map: Jeff T. Price

Cover Art: Christopher M. Goldade

Major Funding: Prairie Pothole Joint Venture, U.S. Fish and Wildlife Service U.S. Geological Survey

Funding also provided by: U.S. Forest Service

The Nature Conservancy

\section{Collaborators:}

Louis B. Best, Iowa State University

Carl E. Bock, University of Colorado

Brenda C. Dale, Canadian Wildlife Service

Stephen K. Davis, Saskatchewan Wetland Conservation Corporation

James J. Dinsmore, Iowa State University

James K. Herkert, Illinois Endangered Species Protection Board

Fritz L. Knopf, Midcontinent Ecological Science Center

Rolf R. Koford, Iowa Cooperative Fish and Wildlife Research Unit

David R. C. Prescott, Alberta NAWMP Centre

Mark R. Ryan, University of Missouri

David W. Sample, Wisconsin Department of Natural Resources

David A. Swanson, Ohio Division of Wildlife

Peter D. Vickery, Massachusetts Audubon Society

John L. Zimmerman (retired), Kansas State University

March 1999

(revised January 2002) 


\section{ORGANIZATION AND FEATURES OF THIS SPECIES ACCOUNT}

Information on the habitat requirements and effects of habitat management on grassland birds were summarized from information in more than 4,000 published and unpublished papers. A range map is provided to indicate the relative densities of the species in North America, based on Breeding Bird Survey (BBS) data. Although birds frequently are observed outside the breeding range indicated, the maps are intended to show areas where managers might concentrate their attention. It may be ineffectual to manage habitat at a site for a species that rarely occurs in an area. The species account begins with a brief capsule statement, which provides the fundamental components or keys to management for the species. A section on breeding range outlines the current breeding distribution of the species in North America, including areas that could not be mapped using BBS data. The suitable habitat section describes the breeding habitat and occasionally microhabitat characteristics of the species, especially those habitats that occur in the Great Plains. Details on habitat and microhabitat requirements often provide clues to how a species will respond to a particular management practice. A table near the end of the account complements the section on suitable habitat, and lists the specific habitat characteristics for the species by individual studies. A special section on prey habitat is included for those predatory species that have more specific prey requirements. The area requirements section provides details on territory and home range sizes, minimum area requirements, and the effects of patch size, edges, and other landscape and habitat features on abundance and productivity. It may be futile to manage a small block of suitable habitat for a species that has minimum area requirements that are larger than the area being managed. The Brown-headed Cowbird (Molothrus ater) is an obligate brood parasite of many grassland birds. The section on cowbird brood parasitism summarizes rates of cowbird parasitism, host responses to parasitism, and factors that influence parasitism, such as nest concealment and host density. The impact of management depends, in part, upon a species' nesting phenology and biology. The section on breeding-season phenology and site fidelity includes details on spring arrival and fall departure for migratory populations in the Great Plains, peak breeding periods, the tendency to renest after nest failure or success, and the propensity to return to a previous breeding site. The duration and timing of breeding varies among regions and years. Species' response to management summarizes the current knowledge and major findings in the literature on the effects of different management practices on the species. The section on management recommendations complements the previous section and summarizes specific recommendations for habitat management provided in the literature. If management recommendations differ in different portions of the species' breeding range, recommendations are given separately by region. The literature cited contains references to published and unpublished literature on the management effects and habitat requirements of the species. This section is not meant to be a complete bibliography; a searchable, annotated bibliography of published and unpublished papers dealing with habitat needs of grassland birds and their responses to habitat management is posted at the Web site mentioned below.

This report has been downloaded from the Northern Prairie Wildlife Research Center WorldWide Web site, www.npwrc.usgs.gov/resource/literatr/grasbird/grasbird.htm. Please direct comments and suggestions to Douglas H. Johnson, Northern Prairie Wildlife Research Center, U.S. Geological Survey, 8711 37th Street SE, Jamestown, North Dakota 58401; telephone: 701253-5539; fax: 701-253-5553; e-mail: Douglas_H_Johnson@usgs.gov. 


\section{LE CONTE'S SPARROW}

(Ammodramus leconteii)

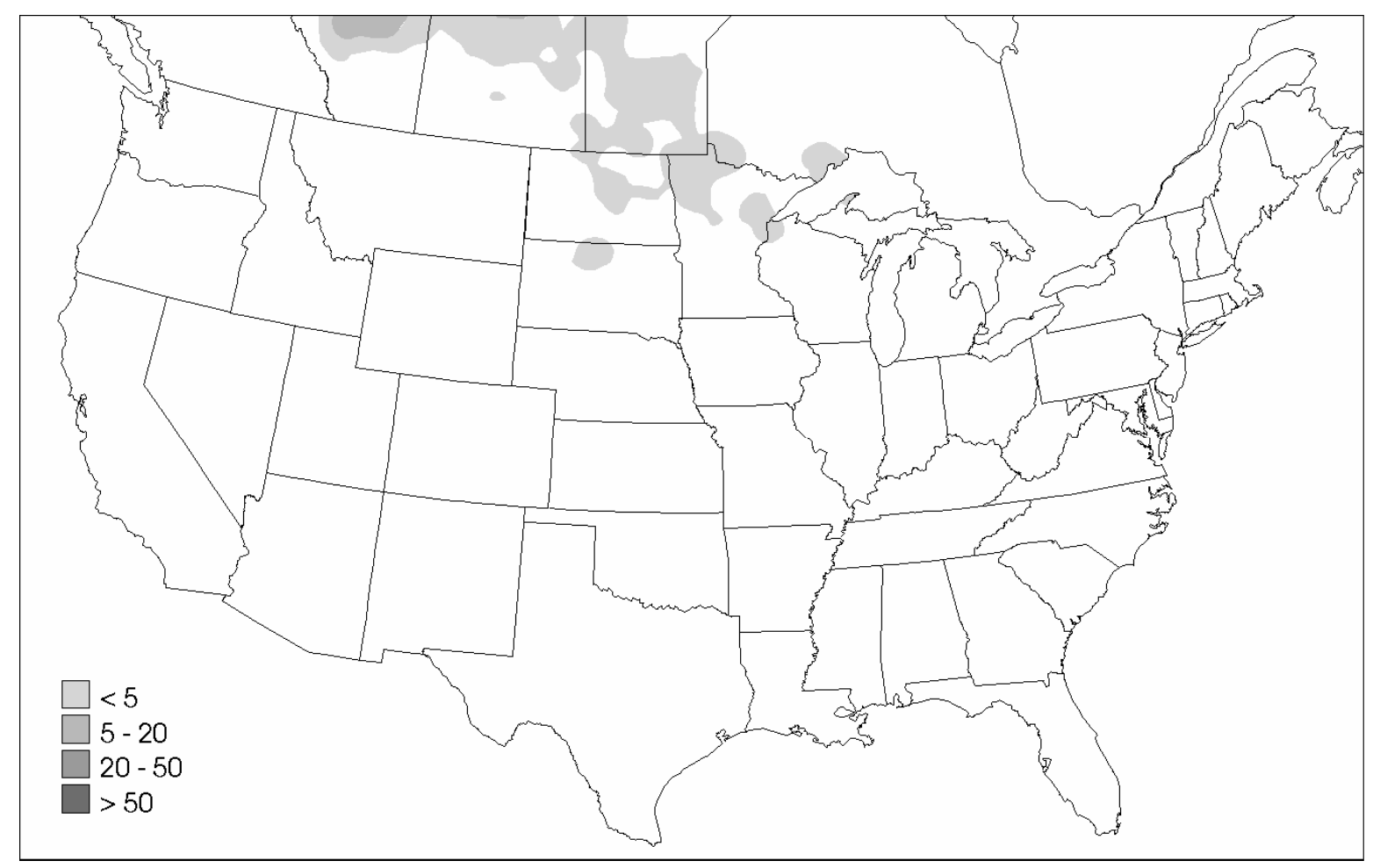

Figure. Breeding distribution of the Le Conte's Sparrow in the United States and southern Canada, based on Breeding Bird Survey data, 1985-1991. Scale represents average number of individuals detected per route per year. Map from Price, J., S. Droege, and A. Price. 1995. The summer atlas of North American birds. Academic Press, London, England. 364 pages.

Keys to management include controlling succession and providing level uplands and lowlands, with tall, thick herbaceous vegetation and thick litter.

\section{Breeding range:}

Le Conte's Sparrows breed from the southern Northwest Territories through southcentral Manitoba and southern Quebec, south to northcentral Montana and northern South Dakota, and east to northern Minnesota, northwestern Wisconsin, and southwestern Ontario (National Geographic Society 1987). (See figure for the relative densities of Le Conte's Sparrows in the United States and southern Canada, based on Breeding Bird Survey data.) In recent years, the species has been observed south of its normal breeding range (Igl and Johnson 1999).

Suitable habitat:

Le Conte's Sparrows use open, level uplands and lowlands, with tall, thick herbaceous vegetation and thick litter (Peabody 1901, Tester and Marshall 1961, Walkinshaw 1968, Murray 1969, Richter 1969). Wetlands, sedge meadows, prairie, grasslands within aspen parkland, planted cover (e.g., Conservation Reserve Program [CRP] fields, Permanent Cover Program [PCP] fields, and dense nesting cover [DNC]), hayfields, fallow fields, and idle pasture all support breeding populations (Peabody 1901; Walkinshaw 1937; Murray 1969; Richter 1969; 
Robbins 1969; Stewart 1975; Renken 1983; Cooper 1984; Niemi 1985; Renken and Dinsmore 1987; Dale 1993; Dhol et al. 1994; Hartley 1994; Jones 1994; Igl and Johnson 1995, 1999; Igl 1996; Dale et al. 1997; McMaster and Davis 1998; Prescott and Murphy 1999; Horn and Koford 2000).

Many species of tall, dense, native and tame grasses, sedges (Carex), rushes (Juncus), and forbs can provide suitable habitat (Peabody 1901, Walkinshaw 1968, Murray 1969, Faanes 1981, Renken 1983, Cooper 1984, Niemi 1985; Renken and Dinsmore 1987, Dale 1993, Jones 1994, Madden 1996). Le Conte’s Sparrows prefer areas with dense litter for nesting cover (Tester and Marshall 1961, Madden 1996). In Minnesota and North Dakota, Le Conte's Sparrows bred in hummocky alkali fens, tallgrass prairie, wet-meadow zones of wetlands, tame hayfields, and retired cropland (Johnsgard 1979). Le Conte's Sparrows nested on the ground in dense herbaceous vegetation, usually in the drier borders of wetlands. Although Le Conte's Sparrows nested among scattered small willows (Salix) in Minnesota and Michigan, they seemed to prefer areas free of shrubs and other woody vegetation (Peabody 1901, Walkinshaw 1968, Robbins 1969, Madden 1996). In North Dakota, Le Conte’s Sparrows were associated with a high amount of grass cover, especially broad-leaved, introduced grasses (Madden 1996).

Habitat use varies widely by region and yearly moisture conditions. In Montana, singing Le Conte's Sparrows were observed in extensive wet meadows (Davis 1952). In North Dakota, Minnesota, and the Canadian prairie provinces, Le Conte's Sparrows used freshwater wetlands and low wet prairie (Murray 1969). In Minnesota, three of 15 nests found were located in upland grasslands (Peabody 1901). More recent studies have found Le Conte's Sparrows breeding in drier upland areas. In Wisconsin and Minnesota, Le Conte's Sparrows nested in dry upland grasslands, as well as in fallow fields near wetlands (Robbins 1969, Cooper 1984). In CRP fields in the northern Great Plains, Le Conte's Sparrows occurred in both damp, low areas and dry, upland areas (Igl and Johnson 1995, 1999). In North Dakota, low, wet areas were optimal breeding habitat, but Le Conte's Sparrows also nested in domestic hayfields and retired cropland (Stewart 1975).

In aspen parkland in Saskatchewan and Alberta, Le Conte's Sparrows were not observed in cropland, including fallow cropland (Dale 1993, Hartley 1994, Prescott and Murphy 1999). In North Dakota, singing male Le Conte's Sparrows were observed in small-grain fields that were CRP the previous year (L. D. Igl and D. H. Johnson, unpublished data). The Le Conte's Sparrow's presence in these small-grain fields, however, may have been an expression of site fidelity to a previous breeding site. In Manitoba, Le Conte's Sparrows were not detected in cropland (Jones 1994). In Alberta, Manitoba, and Saskatchewan, Le Conte’s Sparrows occurred more frequently in PCP grasslands than in cropland (McMaster and Davis 1998). PCP was a Canadian program that paid farmers to seed highly erodible land to perennial grassland cover; it differed from CRP in the United States in that haying and grazing were allowed annually in PCP. In a Saskatchewan study comparing bird use of uplands and wetlands in conventional, minimum-tillage, and organic farmland and DNC, Le Conte's Sparrows were present only in organic farmland and DNC in uplands and in all but wetlands within minimum-tillage farmland (Shutler et al. 2000). In uplands, Le Conte's Sparrows were more abundant in DNC than in organic farmland. They were more abundant in wetlands within organic farmland than wetlands within conventional farmland or DNC. A table near the end of the account lists the specific habitat characteristics for Le Conte’s Sparrows by study. Area requirements: 
Little information is available regarding the area requirements of the Le Conte's Sparrow. No studies have investigated a relationship between patch size and nest success or patch size and rates of brood parasitism by Brown-headed Cowbirds (Molothrus ater). Estimates of breeding territory sizes in North Dakota and Minnesota were 0.2 ha (Murray 1969, Cooper 1984). Le Conte's Sparrows showed no relationship between frequency of occurrence and patch size in CRP fields in the northern Great Plains (D. H. Johnson, unpublished data).

Brown-headed Cowbird brood parasitism:

Brood parasitism by Brown-headed Cowbirds has been reported, but the effect on productivity is unknown (Peabody 1901, Friedmann 1963, Murray 1969, Friedmann and Kiff 1985). Rates of parasitism vary from $2 \%$ of 51 nests (M. Winter and D. H. Johnson, unpublished data) to $29 \%$ of 14 nests (Peabody 1901).

Breeding-season phenology and site fidelity:

The breeding season of the Le Conte's Sparrow extends from about early May until late August or early September (Murray 1969, Stewart 1975, Faanes 1981, Lowther 1996). Le Conte's Sparrow populations show drastic local fluctuations, probably due to changes in moisture conditions (Peabody 1901; Stewart 1975; Igl and Johnson 1995, 1999; Madden 1996). Influxes or dramatic increases in abundance often are correlated with the return of moisture following a drought period (Peabody 1901; Stewart 1975; Igl and Johnson 1995, 1999; Lowther 1996). Le Conte's Sparrows will renest following the loss of a nest, but double-brooding has not been observed (Bent 1968, Johnsgard 1979).

Species' response to management:

Periodic treatments such as burning, mowing, grazing, or combinations thereof, may be needed to maintain optimal habitat for the species. Although little information is available, Le Conte's Sparrows seem to respond favorably to the effects of fire in some parts of their range. In North Dakota mixed-grass prairie, the species increased in abundance with repeated fires but was absent from prairies that had not been burned for long periods (Madden 1996). Le Conte's Sparrows reached highest abundance 2 yr postburn and would probably benefit from short (2-4 yr) fire intervals (Madden 1996, Madden et al. 1999). Abundance was highest in grasslands that had been burned four times in the previous $15 \mathrm{yr}$, compared to unburned areas and areas burned one to two times in the previous 15 yr. Le Conte's Sparrows in Minnesota avoided burned areas immediately after burning, but were present the following year after litter and vegetation regrowth increased (Tester and Marshall 1961).

Annual haying often negatively influences breeding Le Conte's Sparrows (Murray 1969, Lowther 1996, Dale et al. 1997). In addition to direct destruction of nests by mowing, repeated mowing reduces the dense litter layer preferred by the species (Dale et al. 1997). In Saskatchewan, Le Conte's Sparrows preferred periodically mowed (idle for 3-8 yr) tame hayland over annually mowed tame hayland and idle mixed-grass prairie (Dale et al. 1997). Le Conte's Sparrows were absent from both mowed and unmowed annual hayland. Comparing recently mowed periodic hayland, Le Conte's Sparrows were more abundant on unmowed hayland than on mowed hayland. Hayfields mowed at $>1 \mathrm{yr}$ intervals provide stands of introduced, broadleaved grasses attractive to Le Conte's Sparrows (Dale et al. 1997). In southern Saskatchewan hayfields, number of pairs was not affected by amount of cropland or wetland within $1.6 \mathrm{~km}$ of study areas (McMaster et al. 1999). In Minnesota, only five of 24 territories were within 
annually cut hayland; the remaining territories were mostly in idle grass and fallow fields (Cooper 1984). In North Dakota, however, highest abundances of Le Conte's Sparrows occurred on hayland that had been mowed 1 yr previously, providing tall grass growth that was preferred for nesting (Kantrud 1981). In another North Dakota, study, Le Conte’s Sparrows were marginally more abundant in the year after mowing in idled portions of CRP fields than in mowed portions (Horn and Koford 2000).

Effects of grazing on Le Conte’s Sparrows are not clear (Bock et al. 1993). Le Conte’s Sparrows used actively grazed areas in Minnesota and idle pastures in both Minnesota and Wisconsin, provided that adequate litter was present (Tester and Marshall 1961, Robbins 1969). In Alberta aspen parkland, Le Conte's Sparrows occurred more frequently in tame pasture than in native pasture (Prescott and Murphy 1996). In tame pasture, Le Conte’s Sparrows preferred high grass biomass; in native pasture, low to moderate cover diversity and moderate to tall grass of uniform height were preferred (Prescott and Murphy 1996).

In the northern Great Plains (Minnesota, North Dakota, South Dakota, Montana), Le Conte's Sparrows breed in thick, undisturbed cover provided by DNC, and CRP plantings (Renken 1983; Renken and Dinsmore 1987; Igl and Johnson 1995, 1999). In North Dakota, Le Conte's Sparrows used DNC fields of alfalfa (Medicago sativa) and intermediate and tall wheatgrass (Agropyron intermedium and A. elongatum, respectively) that were idle for 6-9 yr (Renken and Dinsmore 1987). However, idling habitat for $>1$ yr in a Minnesota tallgrass prairie allowed too much litter accumulation for use by Le Conte's Sparrows (Tester and Marshall 1961).

In Canadian aspen parkland, Le Conte's Sparrows regularly breed in DNC plantings (Dale 1993, Prescott and Murphy 1999). In Saskatchewan, Le Conte's Sparrows bred in native and tame DNC that was 3-5 yr old (Hartley 1994). In Alberta, Le Conte's Sparrows were rare or absent in DNC that were $<2$ yr old, increased in abundance through the fifth year, and decreased in abundance after the fifth year (Prescott and Murphy 1999). In that study, DNC was mostly tame, although a native component was present. Dale (1993) found Le Conte's Sparrows in tame DNC planted to intermediate and tall wheatgrass, alfalfa, and sweet clover (Melilotus) in Saskatchewan. Le Conte's Sparrows also were very common in low nesting cover composed of Kentucky bluegrass (Poa pratensis) and creeping red fescue (Festuca rubra) (Dale 1993). Prescott et al. (1995) found that Le Conte's Sparrows were abundant in both native and tame DNC in Alberta. In Alberta, Manitoba, and Saskatchewan, the frequency of occurrence of Le Conte's Sparrows was higher in hayed PCP sites than in grazed PCP sites (McMaster and Davis 1998).

Le Conte's Sparrows were detected in native grassland, native DNC, tame DNC, and hayland in Manitoba (Jones 1994). In another Manitoba study, Le Conte's Sparrows were more abundant in native DNC than in idle native grasslands, but no difference in abundance was found between native and tame DNC or between tame DNC and native grasslands; no difference in productivity among the three habitats was detected (Dhol et al. 1994). 


\section{Management Recommendations:}

Timing and type of management must be adjusted according to regional differences and annual precipitation.

Protect grasslands through conservation easements, land purchases, and development of farm programs that hold conservation of wildlife habitat in high priority (Johnson 1996, McMaster and Davis 1998).

Burn every 2-4 yr in mesic, mixed-grass prairie. Le Conte’s Sparrows in North Dakota reached highest abundances 2 yr postburn and avoided unburned prairie (Madden 1996, Madden et al. 1999).

Avoid annual mowing, which can destroy nests and reduce dense litter needed for nesting (Murray 1969, Lowther 1996, Dale et al. 1997).

In Saskatchewan, dense cover can be maintained by mowing some fields in alternate years while leaving others idle for at least $3 \mathrm{yr}$ (Dale et al. 1997). Grasslands mowed at longer (2-9 yr) intervals also may be suitable (Renken and Dinsmore 1987).

If fields need to be mowed at $<2$ yr intervals, ensure productivity of hay and of birds by dividing large fields in half, mowing each half in alternate years (Dale et al. 1997). If possible, delay mowing of hayfields until after 15 July or until after the majority of nests have fledged young (Dale et al. 1997).

Discourage mowing or grazing of CRP land during extremely wet years, because disturbance will negatively impact breeding Le Conte's Sparrows (Igl and Johnson 1995). CRP and DNC plantings can provide tall, dense nesting habitat (Renken and Dinsmore 1987; Igl and Johnson 1995, 1999).

Do not leave habitat idle for so long as to allow over-accumulation of litter. Tester and Marshall (1961) suggested that idling for $>1$ yr in Minnesota tallgrass may allow litter to build up too high for use by Le Conte's Sparrows. Mow periodically to maintain suitable habitat and prevent woody-vegetation encroachment (Robbins 1969, Kantrud 1981, Dale et al. 1997). 
Table. Le Conte’s Sparrow habitat characteristics.

\begin{tabular}{|c|c|c|c|}
\hline Author(s) & Location(s) & Habitat(s) Studied* & Species-specific Habitat Characteristics \\
\hline Cooper 1984 & Minnesota & $\begin{array}{l}\text { Cropland, idle } \\
\text { tallgrass, idle tame, } \\
\text { tame hayland, wetland }\end{array}$ & $\begin{array}{l}\text { Bred in hayland, dry uplands, and fallow fields near wetlands; } \\
\text { territories included shrubs, wet grasses, sedges (Carex), and crops }\end{array}$ \\
\hline Dale 1993 & Saskatchewan & $\begin{array}{l}\text { Cropland, dense } \\
\text { nesting cover (DNC; } \\
\text { idle tame), idle, low } \\
\text { nesting cover (idle } \\
\text { tame) }\end{array}$ & $\begin{array}{l}\text { Were present in two types of 2-yr-old planted cover: creeping red } \\
\text { fescue (Festuca rubra)/Kentucky bluegrass (Poa pratensis) and } \\
\text { tame DNC planted to wheatgrass (Agropyron), alfalfa (Medicago } \\
\text { sativa), and sweet clover (Melilotus); were absent from cropland }\end{array}$ \\
\hline Dale et al. 1997 & Saskatchewan & $\begin{array}{l}\text { Idle mixed-grass, } \\
\text { idle tame, tame } \\
\text { hayland }\end{array}$ & $\begin{array}{l}\text { Preferred idle tame hayland to idle mixed-grass or annually } \\
\text { mowed tame hayland; preferred tame hayland unmowed for } 6 \text { yr } \\
\text { over tame hayland mowed } 2 \text { yr previously }\end{array}$ \\
\hline Davis 1952 & Montana & $\begin{array}{l}\text { Idle tame, wet } \\
\text { meadow, wetland }\end{array}$ & $\begin{array}{l}\text { Used extensive wet meadows of timothy (Phleum pratense) and } \\
\text { redtop (Agrostis stolonifera) }\end{array}$ \\
\hline Dhol et al. 1994 & Manitoba & $\begin{array}{l}\text { DNC (idle seeded - } \\
\text { native, idle tame), } \\
\text { idle mixed-grass }\end{array}$ & $\begin{array}{l}\text { Were more abundant in DNC seeded to native vegetation } \\
\text { (dominant plant species were western wheatgrass [Pascopyrum } \\
\text { smithii], thick-spike wheatgrass [Agropyron dasystachyum], } \\
\text { streambank wheatgrass [Agropyron riparium], slender wheatgrass } \\
\text { [Agropyron caninum], green needlegrass [Stipa viridula], big } \\
\text { bluestem [Andropogon gerardii], switchgrass [Panicum } \\
\text { virgatum], and purple prairie clover [Dalea purpurea]) than in } \\
\text { mixed-grass prairie; abundance was not different between native } \\
\text { DNC and tame DNC (tall wheatgrass [Agropyron elongatum], } \\
\text { intermediate wheatgrass [Agropyron intermedium], slender } \\
\text { wheatgrass, and alfalfa), or between tame DNC and mixed-grass } \\
\text { prairie; Le Conte's Sparrow productivity was not different among } \\
\text { habitats }\end{array}$ \\
\hline
\end{tabular}




\begin{tabular}{|c|c|c|c|}
\hline Faanes 1981 & $\begin{array}{l}\text { Minnesota, } \\
\text { Wisconsin }\end{array}$ & $\begin{array}{l}\text { Cropland, idle, idle } \\
\text { tallgrass/tame, shrub } \\
\text { carr, tame hayland, } \\
\text { tame pasture, wet } \\
\text { meadow, wetland, } \\
\text { woodland }\end{array}$ & $\begin{array}{l}\text { Used sedge meadows; also observed in drier upland grasslands } \\
\text { (timothy, brome [Bromus]), Kentucky bluegrass). }\end{array}$ \\
\hline Hartley 1994 & Saskatchewan & $\begin{array}{l}\text { Cropland, DNC (idle } \\
\text { seeded-native, idle } \\
\text { seeded-native/tame, } \\
\text { idle tame, idle tame } \\
\text { hayland), idle mixed- } \\
\text { grass }\end{array}$ & $\begin{array}{l}\text { Observed in DNC and mixed-grass prairie; were absent from } \\
\text { wheat fields }\end{array}$ \\
\hline $\begin{array}{l}\text { Horn and Koford } \\
2000\end{array}$ & North Dakota & $\begin{array}{l}\text { CRP (idle tame, tame } \\
\text { hayland) }\end{array}$ & $\begin{array}{l}\text { Were marginally more abundant in the year after mowing in idled } \\
\text { portions of CRP fields than in mowed portions }\end{array}$ \\
\hline $\begin{array}{l}\text { Igl and Johnson } \\
1995,1999\end{array}$ & $\begin{array}{l}\text { Minnesota, } \\
\text { Montana, } \\
\text { North Dakota, } \\
\text { South Dakota }\end{array}$ & $\begin{array}{l}\text { Conservation Reserve } \\
\text { Program (CRP; idle } \\
\text { tame, tame hayland, } \\
\text { tame pasture) }\end{array}$ & $\begin{array}{l}\text { Were present in dry as well as damp upland areas; most dramatic } \\
\text { population increases occurred in cover of tall, western, and } \\
\text { intermediate wheatgrasses, smooth brome (B. inermis), and alfalfa }\end{array}$ \\
\hline Johnsgard 1979 & $\begin{array}{l}\text { Minnesota, } \\
\text { North Dakota }\end{array}$ & $\begin{array}{l}\text { Idle, idle tallgrass, } \\
\text { tame hayland, wetland }\end{array}$ & $\begin{array}{l}\text { Nested in alkali fens, tallgrass prairie, wet-meadow zones of } \\
\text { wetlands, tame hayfields, and retired cropland; nested on the } \\
\text { ground in dense herbaceous vegetation, usually in the drier } \\
\text { borders of wetlands }\end{array}$ \\
\hline Jones 1994 & Manitoba & $\begin{array}{l}\text { Cropland, DNC (idle } \\
\text { seeded-native, idle } \\
\text { tame), idle mixed- } \\
\text { grass, idle tame, tame } \\
\text { hayland, woodland }\end{array}$ & Were present in all habitat types except cropland \\
\hline Kantrud 1981 & North Dakota & Mixed-grass hayland, & Abundance was greatest in grassland mowed 1 yr previously that \\
\hline
\end{tabular}




\begin{tabular}{|c|c|c|c|}
\hline & & mixed-grass pasture & provided tall grass, but not deep litter \\
\hline Madden 1996 & North Dakota & $\begin{array}{l}\text { Burned mixed-grass, } \\
\text { burned tame, idle } \\
\text { mixed-grass, idle tame }\end{array}$ & $\begin{array}{l}\text { Preferred low shrub cover and high grass cover, especially broad- } \\
\text { leaved introduced grasses such as smooth brome and quackgrass } \\
\text { (Agropyron repens) }\end{array}$ \\
\hline $\begin{array}{l}\text { McMaster and } \\
\text { Davis } 1998\end{array}$ & $\begin{array}{l}\text { Alberta, } \\
\text { Manitoba, } \\
\text { Saskatchewan }\end{array}$ & $\begin{array}{l}\text { Cropland, Permanent } \\
\text { Cover Program (PCP; } \\
\text { idle tame, tame } \\
\text { hayland, tame pasture) }\end{array}$ & $\begin{array}{l}\text { Occurred more frequently in PCP than in cropland; frequency of } \\
\text { occurrence was higher in hayed PCP sites than in grazed PCP sites }\end{array}$ \\
\hline $\begin{array}{l}\text { McMaster et al. } \\
1999\end{array}$ & Saskatchewan & $\begin{array}{l}\text { Hayland, PCP (tame } \\
\text { hayland) }\end{array}$ & $\begin{array}{l}\text { Amount of cropland or wetland within } 1.6 \mathrm{~km} \text { of study areas did } \\
\text { not affect number of indicated pairs }\end{array}$ \\
\hline Murray 1969 & North Dakota & $\begin{array}{l}\text { Wet- meadow } \\
\text { hayland, wetland }\end{array}$ & $\begin{array}{l}\text { Preferred freshwater wetlands and low, wet prairie; used sheep } \\
\text { sorrel (Rumex acetosella) for perches; were commonly found in } \\
\text { prairie cordgrass (Spartina pectinata), occasionally in foxtail } \\
\text { barley (Hordeum jubatum), and rarely in smooth brome; nests } \\
\text { were made of prairie cordgrass and covered with dense litter }\end{array}$ \\
\hline Niemi 1985 & Minnesota & Peatland & $\begin{array}{l}\text { Were found in more open areas with a high density of sedges, } \\
\text { moderate forb densities, and low overall vegetation heights; mean } \\
\text { (or median) vegetation values were } 39 \% \text { live ground cover, } 398 \\
\text { stems } / \mathrm{m}^{2} \text { sedge density, } 44 \text { stems } / \mathrm{m}^{2} \text { forb density, } 57 \mathrm{stems} / 25 \mathrm{~m}^{2} \\
\text { shrub density, } 0.66 \mathrm{~m} \text { shrub height, and } 0.9 \mathrm{~m} \text { overall height of } \\
\text { predominant vegetation }\end{array}$ \\
\hline Peabody 1901 & Minnesota & Idle tallgrass, wetland & $\begin{array}{l}\text { Used wet grass or wetlands and tallgrass with scattered short } \\
\text { willows (Salix); bred in thick, dead vegetation and areas with } \\
\text { heavy growth such as timothy and vetch (Vicia); nests were } \\
\text { covered with dense litter; only } 3 \text { of } 15 \text { nests were in upland } \\
\text { grassland }\end{array}$ \\
\hline Prescott and & Alberta & Mixed-grass pasture, & Occurred with higher frequency of occurrence on tame pasture; \\
\hline
\end{tabular}




\begin{tabular}{|c|c|c|c|}
\hline Murphy 1996 & & tame pasture & $\begin{array}{l}\text { occurred in tame pasture in areas with moderate amounts of } \\
\text { herbaceous biomass, low to moderate variation in herbaceous } \\
\text { height, and low proportion of forbs relative to grasses; occurred in } \\
\text { mixed-grass pasture in areas with low cover diversity, tall grass, } \\
\text { and grass of uniform height }\end{array}$ \\
\hline $\begin{array}{l}\text { Prescott and } \\
\text { Murphy } 1999\end{array}$ & Alberta & $\begin{array}{l}\text { Cropland, DNC (idle } \\
\text { seeded-native/tame) }\end{array}$ & $\begin{array}{l}\text { Were rare or absent in }<2 \text {-yr-old DNC planted largely to tame } \\
\text { grasses, although native grasses were present; abundance } \\
\text { increased as the age of DNC stands increased up to } 5 \text { yr, then } \\
\text { average abundance decreased; were not found in cropland }\end{array}$ \\
\hline Prescott et al. 1995 & Alberta & $\begin{array}{l}\text { Cropland, DNC (idle } \\
\text { seeded-native, idle } \\
\text { tame), idle mixed- } \\
\text { grass, idle parkland, } \\
\text { idle tame, mixed-grass } \\
\text { pasture, parkland } \\
\text { pasture, tame hayland, } \\
\text { tame pasture, wetland, } \\
\text { woodland }\end{array}$ & $\begin{array}{l}\text { Were abundant in native and tame DNC; were uncommon in } \\
\text { freshwater wetlands; were absent from continuously grazed native } \\
\text { parkland, idle deciduous upland, cropland, small and medium } \\
\text { saline wetlands, and shelterbelts }\end{array}$ \\
\hline $\begin{array}{l}\text { Renken 1983, } \\
\text { Renken and } \\
\text { Dinsmore } 1987\end{array}$ & North Dakota & $\begin{array}{l}\text { DNC (idle tame), idle } \\
\text { mixed-grass, mixed- } \\
\text { grass pasture }\end{array}$ & $\begin{array}{l}\text { Territories were located in areas with higher grass cover and } \\
\text { higher effective height than unoccupied areas; mean vegetation } \\
\text { values (percent cover for each life form was measured and } \\
\text { calculated separately) for occupied areas were } 88.8 \% \text { grass cover, } \\
35.4 \% \text { forb cover, } 99.0 \% \text { litter cover, } 0.0 \% \text { shrub cover, } 0.3 \% \\
\text { bare ground, } 41 \mathrm{~cm} \text { effective height, and } 2.4 \mathrm{~cm} \text { litter depth }\end{array}$ \\
\hline Richter 1969 & Wisconsin & Idle tallgrass, wetland & $\begin{array}{l}\text { Nested in dense vegetation of low, moist areas and thick, uncut } \\
\text { and unburned weedy meadows }\end{array}$ \\
\hline Robbins 1969 & Wisconsin & $\begin{array}{l}\text { Idle pasture, idle } \\
\text { tallgrass, tame } \\
\text { hayland, wetland }\end{array}$ & $\begin{array}{l}\text { Preferred upland grass meadows without woody vegetation and } \\
\text { large, relatively flat areas of undisturbed pasture and timothy hay; } \\
\text { seldom used low, damp areas }\end{array}$ \\
\hline
\end{tabular}




\begin{tabular}{|l|l|l|l|}
\hline Shutler et al. 2000 & Saskatchewan & $\begin{array}{l}\text { Cropland, DNC (idle } \\
\text { seeded-native, idle } \\
\text { seeded-tame), wetland } \\
\text { present in minimum-tillage or conventional farmland in uplands or } \\
\text { in wetlands within minimum-tillage farmland; in uplands, were } \\
\text { more abundant in DNC than in organic farmland; were more } \\
\text { abundant in wetlands within organic farmland than wetlands } \\
\text { within conventional farmland or DNC }\end{array}$ & $\begin{array}{l}\text { Were prent in organic farmland and DNC in uplands and in } \\
\text { wetlands within organic and conventional farmland; were not }\end{array}$ \\
\hline Stewart 1975 & North Dakota & $\begin{array}{l}\text { Idle, idle tallgrass, } \\
\text { tame hayland, wetland }\end{array}$ & $\begin{array}{l}\text { Preferred hummocky, alkaline-type bogs; also used low tallgrass } \\
\text { areas and wet-meadow zones of wetlands, tame hayland, and } \\
\text { retired cropland; nested in dense herbaceous vegetation }\end{array}$ \\
\hline $\begin{array}{l}\text { Tester and } \\
\text { Marshall 1961 }\end{array}$ & Minnesota & $\begin{array}{l}\text { Burned tallgrass, idle } \\
\text { tallgrass, tallgrass } \\
\text { hayland, tallgrass } \\
\text { pasture }\end{array}$ & $\begin{array}{l}\text { Used areas with a moderate litter layer (usually 1 yr of } \\
\text { accumulation) and new grass growth of } \geq 30 \text { cm; used grazed and } \\
\text { burned areas (1 yr postburn) }\end{array}$ \\
\hline $\begin{array}{l}\text { Walkinshaw 1937, } \\
\text { 1968 }\end{array}$ & Rangewide & Idle tallgrass, wetland & $\begin{array}{l}\text { Nested in grassy wetlands with softstem bulrush (Schoenoplectus } \\
\text { tabernaemontani) and scattered short willows; nests were placed } \\
\text { in areas susceptible to flooding }\end{array}$ \\
\hline
\end{tabular}

*In an effort to standardize terminology among studies, various descriptors were used to denote the management or type of habitat. "Idle" used as a modifier (e.g., idle tallgrass) denotes undisturbed or unmanaged (e.g., not burned, mowed, or grazed) areas. "Idle” by itself denotes unmanaged areas in which the plant species were not mentioned. Examples of "idle" habitats include weedy or fallow areas (e.g., oldfields), fencerows, grassed waterways, terraces, ditches, and road rights-of-way. "Tame" denotes introduced plant species (e.g., smooth brome [Bromus inermis]) that are not native to North American prairies. "Hayland" refers to any habitat that was mowed, regardless of whether the resulting cut vegetation was removed. "Burned" includes habitats that were burned intentionally or accidentally or those burned by natural forces (e.g., lightning). In situations where there are two or more descriptors (e.g., idle tame hayland), the first descriptor modifies the following descriptors. For example, idle tame hayland is habitat that is usually mowed annually but happened to be undisturbed during the year of the study. 


\section{LITERATURE CITED}

Bock, C. E., V. A. Saab, T. D. Rich, and D. S. Dobkin. 1993. Effects of livestock grazing on Neotropical migratory landbirds in western North America. Pages 296-309 in D. M. Finch and P. W. Stangel, editors. Status and management of Neotropical migratory birds. U.S.D.A. Forest Service, General Technical Report RM-229.

Bent, A. C. 1968. Life histories of North American cardinals, grosbeaks, buntings, towhees, finches, sparrows, and allies. Dover Publications, Inc., New York, New York.

Cooper, S. 1984. Habitat and size of the Le Conte’s Sparrow territory. Loon 56:162-165.

Dale, B. 1993. 1992 Saskatchewan non-game bird evaluation of North American Waterfowl Management Plan: DNC and short grass cover - 1992. Unpublished report. Canadian Wildlife Service, Edmonton, Alberta; Saskatchewan Wetland Conservation Corporation, Regina, Saskatchewan. 23 pages.

Dale, B. C., P. A. Martin, and P. S. Taylor. 1997. Effects of hay management on grassland songbirds in Saskatchewan. Wildlife Society Bulletin 25:616-626.

Davis, D. E. 1952. Le Conte’s Sparrow in western Montana. Condor 54:115-116.

Dhol, S., J. Horton, and R. E. Jones. 1994. 1994 non-waterfowl evaluation on Manitoba’s North American Waterfowl Management Plan. Unpublished report. Wildlife Branch, Manitoba Department of Natural Resources, Winnipeg, Manitoba. 12 pages.

Faanes, C. A. 1981. Birds of the St. Croix River Valley: Minnesota and Wisconsin. U.S. Fish and Wildlife Service, Washington, D.C. North American Fauna 73. 196 pages.

Friedmann, H. 1963. Host relations of the parasitic cowbirds. U.S. National Museum Bulletin 233:1-276.

Friedmann, H., and L. F. Kiff. 1985. The parasitic cowbirds and their hosts. Proceedings of the Western Foundation of Vertebrate Zoology 2:226-304.

Hartley, M. J. 1994. Passerine abundance and productivity indices in grasslands managed for waterfowl nesting cover. Transactions of the North American Wildlife and Natural Resources Conference 59:322-327.

Horn, D. J., and R. R. Koford. 2000. Relation of grassland bird abundance to mowing of Conservation Reserve Program fields in North Dakota. Wildlife Society Bulletin 28:653659.

Igl, L. D. 1996. Le Conte’s, Sharp-tailed, and Henslow’s sparrows in Grant County. Loon 68:127-128.

Igl, L. D., and D. H. Johnson. 1995. Dramatic increase of Le Conte’s Sparrow in Conservation Reserve Program fields in the northern Great Plains. Prairie Naturalist 27:89-94. 
Igl, L. D., and D. H. Johnson. 1999. Le Conte’s Sparrows breeding in Conservation Reserve Program fields: precipitation and patterns of population change. Pages 178-186 in P. D. Vickery and J. R. Herkert, editors. Ecology and conservation of grassland birds of the Western Hemisphere. Studies in Avian Biology 19.

Johnsgard, P. A. 1979. Birds of the Great Plains. University of Nebraska Press, Lincoln, Nebraska. 539 pages.

Johnson, D. H. 1996. Management of northern prairies and wetlands for the conservation of Neotropical migratory birds. Pages 53-67 in F. R. Thompson, III, editor. Management of midwestern landscapes for the conservation of Neotropical migratory birds. U.S.D.A. Forest Service General Technical Report NC-187.

Jones, R. E. 1994. Non-waterfowl evaluation of Manitoba's North American Waterfowl Management Program. Unpublished report. Wildlife Branch, Manitoba Department of Natural Resources, Winnipeg, Manitoba. 15 pages.

Kantrud, H. A. 1981. Grazing intensity effects on the breeding avifauna of North Dakota native grasslands. Canadian Field-Naturalist 95:404-417.

Lowther, P. E. 1996. Le Conte’s Sparrow (Ammodramus leconteii). In A. Poole and F. Gill, editors. The birds of North America, No. 224. The Academy of Natural Sciences, Philadelphia, Pennsylvania; The American Ornithologists’ Union, Washington, D.C.

Madden, E. M. 1996. Passerine communities and bird-habitat relationships on prescribeburned, mixed-grass prairie in North Dakota. M.S. thesis. Montana State University, Bozeman, Montana. 153 pages.

Madden, E. M., A. J. Hansen, and R. K. Murphy. 1999. Influence of prescribed fire history on habitat and abundance of passerine birds in northern mixed-grass prairie. Canadian Field-Naturalist 113:627-640.

McMaster, D. G., and S. K. Davis. 1998. Non-game evaluation of the Permanent Cover Program. Unpublished report. Saskatchewan Wetland Conservation Corporation, Regina, Saskatchewan. $75+$ pages.

McMaster, D. G., J. H. Devries, and S. K. Davis. 1999. An integrated evaluation of cropland conversion in the Missouri Coteau of Saskatchewan: productivity of pintail and other grassland birds. Unpublished report. Saskatchewan Wetland Conservation Corporation, Regina, Saskatchewan; Institute for Wetland and Waterfowl Research, Oak Hammock Marsh, Manitoba; Ducks Unlimited Canada, Oak Hammock Marsh, Manitoba.

Murray, B. G., Jr. 1969. A comparative study of Le Conte's and Sharp-tailed sparrows. Auk 86:199-231.

National Geographic Society. 1987. Field guide to the birds of North America, second edition. National Geographic Society, Washington, D.C. 464 pages. 
Niemi, G. J. 1985. Patterns of morphological evolution in bird genera of New World and Old World peatlands. Ecology 66:1215-1228.

Peabody, P. B. 1901. Nesting habits of Le Conte’s Sparrow. Auk 18:129-134.

Prescott, D. R. C., and A. J. Murphy. 1996. Habitat associations of grassland birds on native and tame pastures of the aspen parkland in Alberta. NAWMP-021. Alberta NAWMP Centre, Edmonton, Alberta. 36 pages.

Prescott, D. R. C., and A. Murphy. 1999. Bird populations in seeded nesting cover on North American Waterfowl Management Plan properties in the aspen parkland of Alberta. Pages 203-210 in P. D. Vickery and J. R. Herkert, editors. Ecology and conservation of grassland birds of the Western Hemisphere. Studies in Avian Biology 19.

Prescott, D. R. C., A. J. Murphy, and E. Ewaschuk. 1995. An avian community approach to determining biodiversity values of NAWMP habitats in the aspen parkland of Alberta. NAWMP-012. Alberta NAWMP Centre, Edmonton, Alberta. 58 pages.

Renken, R. B. 1983. Breeding bird communities and bird-habitat associations on North Dakota Waterfowl Production Areas of three habitat types. M.S. thesis. Iowa State University, Ames, Iowa. 90 pages.

Renken, R. B., and J. J. Dinsmore. 1987. Nongame bird communities on managed grasslands in North Dakota. Canadian Field-Naturalist 101:551-557.

Richter, C. H. 1969. The Le Conte’s Sparrow in northeastern Wisconsin. Passenger Pigeon 31:275-277.

Robbins, S. 1969. New light on the Le Conte’s Sparrow. Passenger Pigeon 31:267-274.

Shutler, D., A. Mullie, and R. G. Clark. 2000. Bird communities of prairie uplands and wetlands in relation to farming practices in Saskatchewan. Conservation Biology $14: 1441-1451$.

Stewart, R. E. 1975. Breeding birds of North Dakota. Tri-College Center for Environmental Studies, Fargo, North Dakota. 295 pages.

Tester, J. R., and W. M. Marshall. 1961. A study of certain plant and animal interrelations on a native prairie in northwestern Minnesota. Minnesota Museum of Natural History, Occasional Papers 8:1-51.

Walkinshaw, L. H. 1937. Le Conte's Sparrow breeding in Michigan and South Dakota. Auk 54:309-320.

Walkinshaw, L. H. 1968. Le Conte’s Sparrow (Passerherbulus caudacutus). Pages 765-776 in O. L. Austin, Jr., editor. Life histories of North American cardinals, grosbeaks, buntings, towhees, finches, sparrows, and allies. Dover Publications, Inc., New York, New York. 